\title{
Study of potential activity of clove oil $10 \%$ emulsifiable concentrate formulation on Two-spotted spider Mite Tetranychus urticae Koch (Acari: Tetranychidae)
}

\author{
Hisham I. Abd-Alla \\ Formulation Research Department, Central Agricultural Pesticides Lab. (CAPL), Agriculture \\ Research Center (ARC), Dokki, Giza, Egypt \\ Saad E. S. Hamouda* \\ Formulation Research Department, Central Agricultural Pesticides Lab. (CAPL), Agriculture \\ Research Center (ARC), Dokki, Giza, Egypt \\ ${ }^{*}$ Corresponding author. Email: saad_capl@yahoo.com
}

\section{Article Info}

https://doi.org/10.31018/

jans.v13i4.3124

Received: October 25, 2021

Revised: November 30, 2021

Accepted: December 3, 2021

\section{How to Cite}

Abd-Alla, H.I. and Hamouda, S.E.S. (2021). Study of potential activity of clove oil $10 \%$ emulsifiable concentrate formulation on Two-spotted spider Mite Tetranychus urticae Koch (Acari: Tetranychidae). Journal of Applied and Natural Science, 13(4), 1414 - 1419. https://doi.org/10.31018/jans.v13i4.3124

\begin{abstract}
Clove oil is reported to have a great range of biological activities against many species of pests; termites, cockroaches, aphids, weevils and moths, and many different usages such as perfume and food flavoring agent. This study aimed to determine the acaricidal activity of clove oil emulsifiable concentrate new formulation against two-spotted spider mites Tetranychus urticae. Clove oil was formulated as $10 \%$ emulsifiable concentrate (EC). The new formula passed successfully all physical and chemical tests reported for emulsifiable concentrates. It was then tested biologically on the individuals of two-spotted spider mite $T$. urticae Koch (Acari: Tetranychidae) on two host plants beans and squash under laboratory conditions. In both cases, there were a direct relationship between the increase in the concentration of the formulation and the percentage of inhibition on the individuals of the two-spotted spider mite, after 72 hours of treatment, at concentrations of 20,40 , and $80 \mathrm{mg} / \mathrm{ml}$ the new formulation showed $10.30,44.8$, and 75 percent inhibition, respectively in case of beans, while squash at the same concentrations and for the same period of treatment showed 33.3, 40.7, and 51.9 percent inhibition, but the effect in case of beans was greater than that in case of squash as its $\mathrm{EC}_{50}$ value was lower than that in case of squash. In the case of the former, it was $39.81 \mathrm{mg} /$ $\mathrm{ml}$, whereas in the case of the latter, it was $79.43 \mathrm{mg} / \mathrm{ml}$. Therefore, the new clove oil formulation can be used to combat the two-spotted spider mite.
\end{abstract}

Keywords: Clove oil, Emulsifiable Concentrate Formulation, Spider mite, Tetranychus urticae

\section{INTRODUCTION}

Clove oil is derived from the clove plant Syzygium aromaticum, and is an essential oil. Its insecticidal and repellant properties against a variety of pests have been extensively researched (Chaieb et al. 2007, Kafle and Shih 2013, Corte's-Rojas et al., 2014), including Asian citrus psyllid (Mann et al. 2010); termites (Pandey et al. 2012); fire ants (Appel et al. 2004); aphids (Kareem et al. 2012); cockroaches (Sharawi et al. 2013); moths (Birah et al. 2010) and weevils (Mishra et al. 2013). It also acts as a larvicide, pupicide, adulticide, oviposition deterrent, and ovicide against Aedes aegypti, A. albopictus, and Culex quinquefasciatus mosquito vectors (Phasomkusolsil and Soonwera 2012;
Shapiro 2011; Bhat and Kempraj 2009). Clove oil is also commonly used as a fragrance and food flavouring additive. It possesses a wide range of pharmacological effects, including antibacterial, anti-inflammatory, antioxidant, analgesic and anticancer properties (Kamatou et al. 2012).

Archita et al., (2015) investigated the efficacy of clove oil on the red spider mite, Oligonychus coffeae Nietner (Acari: Tetranychidae), which infests tea plants. They found that $O$. coffeae mortality varied depending on the concentrations and duration of the mites' exposure time after application of the oil. Furthermore, clove oil at specific concentrations has been shown to be effective against adult mites.

Two-spotted spider mite (TSSM), Tetranychus urticae 
Koch, is a frequent pest of many crops (Adeney et al. 2009). TSSM infest stems, leaves, and branches, causing varying degrees of damage. They often feed on the leaves, damaging the epidermis and causing stippling, blotching, or bronzing, reducing yield qualitatively and quantitatively. (Abdallah et al., 2009 and Faris et al., 2004). It also develops silk webbing, which is apparent at high infestation levels (Alzoubi and Cobanoglu, 2006), which limits the plant's ability to manufacture carbohydrates and, as a result, lowers total output (Fouly et al., 2019)

Acaricide resistance in phytophagous mites is a regularly rising problem, particularly in $T$. urticae and other Tetranychids (Van Leeuwen et al. 2009). Many populations of the two-spotted spider mite have gained global resistance to a variety of novel acaricides and insecticides during the 1990s (Arthropod Pesticide Resistance Database, http:// www.pesticideresistance.org/). Furthermore, after only a few years of use, two-spotted spider mite populations have evolved a significant level of resistance to newly introduced compounds, with cross-resistance reported to other compounds with the same mode of action.-There have been reports of $T$. urticae developing resistance to pesticides in general and acaricides in particular, such as fenazaquin (Vassiliou and Kitsis, 2013), propargite (Kumari et al., 2015), bifenazate (Van Leeuwen et al., 2006), and spiromesifen (Sato et al., 2016).

An active ingredient is usually combined with various inert components known as additives or adjuvants in a pesticide formulation. The primary goal of additions is to enhance the active ingredient's effectiveness. Spreaders, wetting agents, stickers, foaming agents, and compatibility agents are all common additives (Libs and Salim, 2017).

The objective of this work was to study the acaricidal activity of clove oil emulsifiable concentrate formulation against the two-spotted spider mites $T$. urticae as a new step in the completion of our target program to obtain safe, eco-friendly active ingredients and formulating it in the form of local formulations for the control of spider mites.

\section{MATERIALS AND METHODS}

\section{Tested chemicals}

a) Clove oil: Supplied by Agricultural Development Markets, Nadi El Seid St., Dokki, Giza, b) Surface active agents: Supplied by EL-Gomhoria Co., Cairo, Egypt.

\section{Physico-chemical properties of the new formulation} basic components:

\section{Active ingredients}

a) Solubility: At $20^{\circ} \mathrm{C}$, the total solubility or miscibility of one gram of active ingredient was tested by measuring the volume of distilled water, ethanol, acetone, xylene, and DMF (Nelson and Fiero, 1954). The following equation was used to compute the percent solubility: $\%$ solubility $=W / V \times 100 \quad$.........Eq. 1 Where; $W=$ active ingredient weight, $V=$ volume of solvent required for complete solubility.

b) Free acidity or alkalinity: It was evaluated by using the procedure outlined in World Health Organization guidelines (1979).

\section{Surface active agents}

a) Surface tension: It was calculated by using Du-Nouy tensiometer for solutions containing $0.5 \%(\mathrm{~W} / \mathrm{V})$ surface active agent according to American Society of Testing Materials (ASTMD-1331) (2001).

b) Hydrophilic-lipophilic balance (HLB): A surfactant's solubility in water was used as a useful approximation to its hydrophilic-lipophilic balance (Lynch and Griffin, 1974).

c) Critical micelle concentration (CMC): The concentration of the tested surfactants at which the surface tension of the solution does not decrease as the surfactant concentration increases (CMC), was calculated using the method described by Osipow,(1964).

d) Free acidity or alkalinity: It was determined as previously stated.

\section{Preparation of clove oil as emulsifiable concentrate (EC) formulation}

The novel formula was made using the procedure Soliman (2005) outlined, which involved dissolving clove oil in a sufficient amount of solvent, adding the emulsifying agent, and stirring the solution for 1 hour. The solution was then diluted to $100 \mathrm{~mL}$ using the same solvent used for dissolution, violently agitated to ensure homogeneity, filtered out, and preserved in a tightly sealed vial, and the following physico-chemical parameters for emulsifiable concentrate formulation were determined:

a) Emulsion stability test: It was performed according to FAO/WHO MT 36.3. (2010).

b) Accelerated storage: It was evaluated according to Collaborative International Pesticides Analytical Council (CIPAC M46.1. (1995).

Spray solution at the field dilution rate

The following physico-chemical properties for the spray solution were determined:

a) Surface tension: It was performed as mentioned before.

b) Viscosity: Brookfield viscometer model DVII+Pro was used to determine viscosity, with centipoise being the unit of measurement according to American Society of Testing Materials (ASTM D-2196) (2005).

c) Electrical Conductivity: It was measured with ColeParmer PH/Conductivity meter 1484-44, where $\mu$ mhos is the unit of electrical conductivity measurements according to (Dobrat and Martijn, 1995). 
d) $\mathrm{pH}$ : It was evaluated by using Cole-Parmer $\mathrm{pH}$ conductivity meter 1484-44 according to (Dobrat and Martijn, 1995).

\section{Bioassay}

Efficacy on individuals under laboratory conditions Acaricidal effect of clove oil emulsifiable concentrate formulation on the individuals of the two-spotted spider mites of $T$. Urticae were carried out according to the leaf disk assay conducted according to the method described by Pree et al., (1989). The Acalypha marginata leaf disks $(2.5 \mathrm{~cm}$ in diameter) were dipped in series concentrations of the tested formulation (20000, 40000 and $80000 \mathrm{ppm}$ ). Concentration mortality relation was based on tests with three concentrations of the formulation, and was expressed as $\mathrm{mg} / \mathrm{ml}$ of the active ingredient. The discs were put on wet cotton wool in petri-dish and kept under constant conditions $\left(25 \pm 2{ }^{\circ} \mathrm{C}, 65 \pm 5\right.$ $\%$ relative humidity $(\mathrm{RH})$ and $16: 8$ photoperiod. Ten adult females (one day old) of $T$. urticae were transferred on each disc with a fine brush. Control discs were dipped in distilled water. Tests were repeated 3 replicates for each concentration of each formulation. In addition to the control, the number of live and dead mites was counted $24,48,72,144$, and 168 hours after treatment.

\section{Statistical analysis}

Percentages of mortality were corrected according to Abbott's formula (1925) as follows

Mortality $\%=$ The died number of TSSM counted after treatment / The died number of TSSM counted before treatment $x 100$ .........Eq. 2 and the concentration inhibition regression lines were calculated through the relationship between concentration logarithm and probit percentage mortality, according to the method of Finney (1952) and the toxicity was calculated according to the equation

Toxicity index $=\mathrm{EC}_{50}$ of the most effective compound / $\mathrm{EC}_{50}$ of the tested compound $\mathrm{x} 100 \quad$.........Eq. 3

\section{RESULTS AND DISCUSSION}

Table 1 shows the physico-chemical properties of clove oil. It showed complete solubility in acetone (100\%) and medium solubility in water and xylene (50\%), showing alkaline properties (free alkalinity as sodium hydroxide). The type of formulation limited by the pesticide solubility and its hydrolytic properties (FAO/ WHO Meeting (2002), solubility and free alkalinity results showed that the suitable formulation type for this active ingredient was emulsifiable concentrate.

Clove oil local $10 \%$ emulsifiable concentrate formulation tested for the physical and chemical properties under normal and accelerated storage conditions showed the same value of free alkalinity, in addition, no changes were observed for spontaneity and emulsion stability under both normal and accelerated storage conditions. The new formula demonstrated its ability to retain its physical and chemical properties under both storage conditions (Table 2).

The physico-chemical properties of the spray solution are shown in Table 3. These properties determine to a large extent how far the new formula is effective. The spray solution showed lower surface tension 40.8 dyne/cm compared to that of water 72 dyne/cm of water. According to (Pereira et al., 2016), the decrease of surface tension of pesticide spray solution gives a

Table 1. Physico-chemical properties of clove oil as an active ingredient

\begin{tabular}{llll}
\hline & \multicolumn{2}{c}{ Solubility $\%(\mathrm{~W} / \mathrm{V})$} & $\begin{array}{l}\text { Free alkalinity } \\
\text { as NaOH }\end{array}$ \\
\hline Water & Acetone & Xylene & 8.35 \\
\hline 50 & 100 & 50 & 85 \\
\hline
\end{tabular}

Table 2. Physico-chemical properties of clove oil $10 \%$ emulsifiable concentrate formulation before and after accelerated storage.

\begin{tabular}{|c|c|c|c|c|c|c|c|c|c|c|c|c|c|}
\hline \multicolumn{7}{|c|}{ Before storage } & \multicolumn{7}{|c|}{ After storage } \\
\hline \multicolumn{2}{|c|}{$\begin{array}{l}\text { Spontaneity } \\
\%\end{array}$} & \multicolumn{2}{|c|}{$\begin{array}{l}\text { Emulsion } \\
\text { stability }\end{array}$} & \multicolumn{2}{|l|}{ Foam } & \multirow{2}{*}{$\begin{array}{l}\text { Free } \\
\text { alkalinity } \\
\text { as } \mathrm{NaOH}\end{array}$} & \multicolumn{2}{|c|}{$\begin{array}{l}\text { Spontaneity } \\
\%\end{array}$} & \multicolumn{2}{|c|}{$\begin{array}{l}\text { Emulsion } \\
\text { stability }\end{array}$} & \multicolumn{2}{|l|}{ Foam } & \multirow{2}{*}{$\begin{array}{l}\text { Free } \\
\text { alkalinity } \\
\text { as } \mathrm{NaOH}\end{array}$} \\
\hline Hard & Soft & Hard & Soft & Hard & Soft & & Hard & Soft & Hard & Soft & Hard & Soft & \\
\hline 100 & 100 & pass & Pass & - & - & 0.04 & 100 & 100 & Pass & pass & - & - & 0.04 \\
\hline
\end{tabular}

Table 3. Physico-chemical properties of clove oil EC (emulsifiable concentrate) spray solution with $0.5 \%$ concentration.

\begin{tabular}{lllll}
\hline Surface tension dyne/cm & Viscosity $\mathbf{c m} /$ poise & Electrical conductivity $\boldsymbol{\mu}$ mhos & $\mathrm{pH}$ & 7.8 \\
\hline 40.8 & 10.4 & 56 & 7 & \\
\hline
\end{tabular}


prediction of increasing wettability and spreading on the treated surface, resulting in increasing pesticidal efficiency. Also the increase in viscosity could increase the pesticidal efficacy as stated by (Spanoghe et al., 2007) who reported that increasing viscosity of spray solution cause reduction drift and increase the retention sticking and insecticidal efficiency. Electrical conductivity also affected the efficiency of the pesticide greatly, as the increase in electrical conductivity could increase the biological efficacy of the pesticide as decided by (ElSisi et al., 2011), as they reported that the increase in electrical conductivity of the spray solution would lead to deionization of insecticides and increase its deposit and penetration in the tested surface with a consequence increase in the insecticidal efficiency.

Three successive serial concentrations from clove oil new emulsifiable concentrate tested on (TSSM) individuals on squash as host plant under laboratory conditions are shown in Table 4 . A concentration of $20 \mathrm{mg} /$ $\mathrm{ml}$ inhibited individuals by $3.3,10.3$ and $33.0 \% .40 \mathrm{mg} /$ $\mathrm{ml}$ inhibited individuals by 10.0, 27.6 and $40.7 \%$ whereas $80 \mathrm{mg} / \mathrm{ml}$ showed 26.7, 37.9 and $51.9 \%$ inhibition after 24,48 and 72 hrs. from treatment respec- tively. It was clear that there was a gradual uniform increase in the percentage of inhibition for each concentration with the increase in exposure periods.

Table 5 shows the effect of clove oil EC on the individuals of (TSSM) on beans as a host plant by the three previously mentioned serial concentrations under laboratory conditions. The increase in exposure periods for all tested concentrations resulted in a gradual increase in the percentage of inhibition as in the case of squash, the higher the concentration, the higher the percentage of inhibition $(80 \mathrm{mg} / \mathrm{ml})$ showed the highest effect between all tested concentrations after $168 \mathrm{hrs}$. from exposure. The results could be explained on the basis of the increase of the active ingredient concentration that reaches the active site with the increase of exposure periods, which may also be attributed to the role of surface-active agents (additives) used in the formulation in facilitating the penetration of the pesticide (Fishel, 2010).

LCP lines for the experimentation of clove oil $10 \%$ EC on (TSSM) individuals on squash and beans as host plants under laboratory conditions are represented in Table 6. $\mathrm{EC}_{50}$ and toxicity index showed that the effect

Table 4. Effect of clove oil EC \% on the individuals of (TSSM), Tetranychus urticae on squash as a host plant under laboratory conditions

\begin{tabular}{|c|c|c|c|}
\hline \multirow{2}{*}{$\begin{array}{l}\text { Concentration } \\
\text { Exposure } \\
\text { periods hrs. }\end{array}$} & \multicolumn{3}{|c|}{$\%$ of inhibition at } \\
\hline & 20 & 40 & 80 \\
\hline 24 & 3.3 & 10 & 26.7 \\
\hline 48 & 10.3 & 27.6 & 37.9 \\
\hline 72 & 33.3 & 40.7 & 51.9 \\
\hline
\end{tabular}

Table 5. Effect of clove oil EC \% on the individuals of (TSSM), Tetranychus urticae on beans as a host plant under laboratory conditions

\begin{tabular}{|c|c|c|c|}
\hline \multirow{2}{*}{$\begin{array}{l}\begin{array}{l}\text { Exposure } \\
\text { periods hrs. }\end{array} \\
\begin{array}{l}\text { Concentration } \\
(\mathrm{mg} / \mathrm{ml})\end{array}\end{array}$} & \multicolumn{3}{|c|}{$\%$ of inhibition at } \\
\hline & $20 \mathrm{mg} / \mathrm{ml}$ & $40 \mathrm{mg} / \mathrm{ml}$ & $80 \mathrm{mg} / \mathrm{ml}$ \\
\hline 24 & 00.0 & 20 & 40 \\
\hline 48 & 3.3 & 36.7 & 55.7 \\
\hline 72 & 10.3 & 44.8 & 75 \\
\hline 144 & 17.2 & 55.2 & 79.3 \\
\hline 168 & 40.9 & 77.3 & 100 \\
\hline
\end{tabular}

Table 6. LCP lines of clove oil EC \% on the individuals of (TSSM), Tetranychus urticae on both host plants under laboratory conditions.

\begin{tabular}{|c|c|c|c|c|}
\hline Local Formulation & Host plant & $\mathrm{EC}_{50} \mathrm{mg} / \mathrm{ml}$ & Slope & Toxicity index \\
\hline & Beans & 39.810 & 0.8 & 100 \\
\hline Clove oil EC & Squash & 79.432 & 0.8 & 158 \\
\hline
\end{tabular}

EC: Emulsifiable concentrate 
of clove oil new formula was higher in the case of beans than in the case of squash, the effect that may be attributed to the nutrient components of the host species, but the slope value was the same in both cases indicating the same mode of action of the new formulation on (TSSM) individuals for beans and squash. Agremic $8.4 \%$ SC recommended as acaricide containaing synthesized active ingredients abamectin showed LC $_{50} 0.0000102 \mathrm{mg} / \mathrm{ml}$ against $T$. urticae (Mohammed et al., 2018). Although the recommended acaricide is more effective than clove oil formulation, it has a number of drawbacks, including environmental contamination and resistance as a result of repeated use, whereas clove oil formulation is environmentally friendly because it is made from plant material in addition to the lack of resistance.

\section{Conclusion}

Clove oil was formulated as $10 \%$ emulsifiable concentrate and passed all reported physico-chemical properties. The new formula was tested on the individuals of the two-spotted spider mites $T$. urticae on beans and squash as host plants under laboratory conditions. It showed a good inhibition effect on the individuals on both host plants, although the effect was greater in the case of beans than in the case of squash. The significance of this research stems from the formulation of clove oil as an emulsifiable concentrate, which is a safer alternative to standard synthetic pesticide formulations. As a result, it is suggested that the new clove oil formulation can be used to combat TSSM.

\section{Conflict of interest}

The authors declare that they have no conflict of interest.

\section{REFERENCES}

1. Abbott's, W. S. (1925). A method of computing the effectiveness of an insecticide; J. Econ. Ent. Journal of Economic Entomology, 18(2), 265-267. https:// doi.org/10.1093/jee/18.2.265a

2. Abdallah, A. A., Habashi, N. H., Mahgoub, M. H. A. \& ElSaiedy, E. M. A. (2009), Population dynamics of the twospotted spider mite, Tetranychus urticae Koch in relation to some specific chemical constituents of four pepper cultivars leaves. Minufiya J. Agric. Res., 34 (6), 2179-2189

3. Adeney, d. F. B., Regiane C. O. de F. B., Paul D. N., Leon G. H. \& Odair A. F. (2009). Photosynthetic response of soybean to two-spotted spider mite (Acari: Tetranychydae) injury. Brazilian Archives of Biology and Technology. 52(4), 825-834. https://doi.org/10.1590/ S1516-89132009000400005

4. Alzoubi, S \& Cobanoglu, S. (2006). Studies of determinatrion of the feeding symptoms as pects of spider mites and their damage rate. J. Agric. Fac. C.U., 21(2), 49-56

5. American Society of Testing Materials (2001). Standard test method for surface and interfacial tension of solution D-1331.

6. American Society of Testing Materials (2005). Standard test method for rheological properties of non - nwtonian materials by rotational (brookfield type) viscometer, D2196 Bar Harbor Drive, West Conshohocken, PA 192482959, United States.

7. Appel, A. C., Gehret, M. J. \& Tanley, M. J. (2004). Repellency and toxicity of mint oil granules to red imported fire ants (Hymenoptera: Formicidae). Journal of Economic Entomology,97, 575-580. doi: 10.1603/0022-049397.2.575

8. Archita, B., Somnath, R., Gautam, H., Foridur, R. B., Azizur, R., Dwiban, P. \& Narayanannair, M. (2015) . Clove oil efficacy on the red spider mite, oligonychus coffeae Nietner (Acari: Tetranychidae) infesting tea plants. Proceedings of the Zoological Society 70(1). doi10.1007/ s12595-015-0147-6, https://www.researchgate.net/ publication/279062599, springer, research Gate.

9. Birah, A., Sharma, T. V. S., Singh, S. \& Srivastava, R. C. (2010). Effect of aqueous leaf extract of cloves (Syzygium aromaticum) on growth and development of tobacco caterpillar (Spodoptera litura)..Indian J. Agric. Sci.80, 534-537.

10. Bhat, S. K. \& Kempraj, V. (2009). Biocidal potential of clove oils against Aedes albopictus. a comparative Study. African Journal of Biotechnology. 8(24), 6933-6937.

11. Chaieb, K., Hajlaoui, H., Zmantar, T., Kahla-Nakbi, A. B., Rouabhia, M., Mahdouani K., \& Bakhrouf, A. (2007). The Chemical Composition and Biological Activity of Cloveessential Oil, Eugenia caryophyllata (Syzigium aromaticum L. Myrtaceae): a short review. Phytother.Res.21(6),501506. doi: $10.1002 / p t r .2124$.

12. Collaborative International Pesticides Analytical Council. (1995). Physicochemical methods for technical and formulated pesticides, F, M46.1, Printed in Great Britain by the Block Boar Press LTD. Kings Hedges Cambridge CB492, England.

13. Corte's-Rojas, D. F., deSouza, C. R. F. \& Oliveira, W. P. (2014). Clove (Syzygium aromaticum): a precious spice. Asian Pac. J.Trop.Biomed. 4(2),90-96. doi: 10.1016/ S2221-1691(14)60215-X.

14. Dobrat, W. \& Martijn, A. (1995). Collaborative International Pesticides Analytical Council Limited. F

15. El-Sisi, A. G., Abd El-Mageed, A. E. M., Tmador F. ElAsawi \& Sharkawy, R. A. (2011). Improvement the physico-chemical properties and efficiency of some insecticides formulation by using adjuvants against cotton Spodoptera littoralis (BOISD.). J. Plant Prot. and Path., Mansoura Univ., 2 (8): 757 - 764.

16. FAO/WHO (2002). Manual on development and use of pesticides, prepared by FAO/WHO Joint meeting on pesticide specifications (JMPS), $1^{\text {st }}$ Ed., Rom.

17. FAO/WHO (2010). Manual on Development and Use of FAO and WHO Specifications for Pesticides. (2010). $1^{\text {st }}$ Ed. $3^{\text {rd }}$ Rev. FAO Plant Production and Protection, FAO, Rome.

18. Faris, F. S, Habashy, N. H. \& Iskandar, A. K. F. (2004). Relationship between infestation with different stages of the spider mite, Tetranychus urticae Koch on fifteen Tomato varieties and plant age with special reference to vegetative and yield physical characters. J. Agric. Sci. Mansoura Univ., 29 (6), 3567-3579. 
19. Finney, D. J. (1952). Probit analysis statistical, $2^{\text {nd }} E d$, Cambridge University

20. Fishel, F. M. (2010). Pesticide Formulations UF/IFAS EDIS Publication PI231. http://edis.ifas.ufl.edu/pi081.

21. Fouly, A. H. ; Osman, M. A. \& Omnia O. H. Abdelghany (2019). Effect of nourishment and mutual interference on feeding capacity and lifetable Parameters of Phytoseius plumifer (C. \& F.) (Acari: Phytoseiidae). J. Plant Prot. and Path., Mansoura Univ.,10 (3) 165-169. doi: 10.21608/ jppp.2019.40921

22. Kafle, L. \& Shih, C. J. (2013). Toxicity and repellency of compounds from clove (Syzygium aromaticum) to red imported fire ants Solenopsis invicta (Hymenoptera: Formicidae). J.Econ.Entomol., 106(1),131-135. doi: 10.1603/ ec12230.

23. Kamatou, G. P., Vermaak, I., \& Viljoen, A. M. (2012). Eugenol from the remote maluku islands to the international market place: a review of a remarkable and versatile molecule. Molecules .17(6), 6953-6981. doi: 10.3390/ molecules17066953.

24. Kareem, T. A., Alsara, I. A. M. \& Mahmud, N. A. L. (2012). Bioactive of five aromatic plant oils against aphids oleander Aphis nerii (Aphidae: Homoptera). Diyala. Agric. Sci. J. 4, 177-186

25. Kumari, S., Chauhan, U., Kumari, A. \& Nadda, G., (2015), Comparative toxicities of novel and conventional acaricides against different stages of Tetranychus urticae Koch (Acarina: Tetranychidae). J. Saudi. Soc. Agric. Sci., 16 (2), 191 - 196. https://doi.org/10.1016/j.jssas.2015.06.003

26. Libs, E. S., \& EL Salim, R. A. (2017). Formulation of essential oil pesticides technology and their application. Agricultural Research \& Technology, 9(2), 42 - 60. doi:10.19080/ARTOAJ.2017.09.555759

27. Lynch, M. I. \& Griffin, W. C. (1974). Food emulsions, In: Emulsion technology, by Lissant, K. J., Marcell, Decker, Inc., New York. Mukerjee, P. and K. J. Mysels (1971) Critical Micelle Concentration of Aqueous Surfactant Systems. National Bureau of Standards Washington DC, PP. 1-21.

28. Mann, R. S., Tiwari, S., Smoot, J. M., Rouseff, R. L. \& Stelinski, L.L. (2010). Repellency \& toxicity of plant-based essential oils and their constituents against Diaphorina Citri Kuwayama (Hemiptera: Psyllidae). J. Appl. Entomol. 136: 87-96. https://doi.org/10.1111/j.1439-0418.2010.01 592.x

29. Mishra, B. B., Tripathi, S. P. \& Tripath, C. P. M .(2013). Bioactivity of two plant derived essential oils against Therice Weevils Sitophilus oryzae (L.) (Coleoptera: Curculionidae). Proc. Natl. Acad. Sci. India, B.83,171-175. doi:10.1007/s40011-012-0123-0

30. Mohammed, A. A. S., Wahba, B. S. \& Radwan, A.O. (2018) . Comparative Studies between the Locally Formulated Abamectin and Agremic Gold 8.4\% SC Using Physical, Chemical and Biological Parameters against TwoSpotted Spider Mite, Tetranychusurticae. International Journal of Science and Research, 7(12), 142-147.

31. Nelson, F. G. \& Fiero, G. W. (1954). A selected aromatic fraction naturally occurring in petroleum as insecticides solvents. J. Agric. Food Chem., 4,735-737.

32. Osipow L. I. 1964. Surface Chemistry Theory and Application. Reinhold Publishing Crop, New York, pp. 4736-
4739.

33. Pandey, A., Chattopadhyay, P., Banerjee, S., Pakshirajan, \& Singh L. (2012). Antitermitic activity of plant essential oils and their major constituents against Termite Odontotermes assamensis Holmgren (Isoptera: Termitidae) of North EastIndia.Int.Biodeter.Biodegr.75,63-67. https:// doi.org/10.1016/j.ibiod.2012.09.004

34. Pereira, V. J., Da Cunha, J. P. A. R., De Morais, T. P., de M., Ribeiro-Oliveira, J. P. \& De Morais, J. B. (2016). Physical-cemical properties of pesticides: Concepts, applications, and interactions with the Environment. Biosci. J, Uberlândia, 32(3), 627-641. doi:10.14393/BJ-v32n3a2016 $-31533$

35. Phasomkusolsil, S. \& Soonwera, M. (2012). The effect of herbal essential oils on oviposition deterrent and ovicidal activities of Aedes aegypti (L.), Anopheles dirus (Peyton and Harrison) and culex quinquefasciatus (Say). Tropical Biomedicine 29(1), 138-150.

36. Pree, D. L., Cole, K. J. \& Fisher, P. A. (1989). Comparison of leaf disc and petri dish assays for the assessment of dicofol resistance in populations of european red mite (Acari: Tetranychidae) from southern Ontario. Can. Entomol., 12, 771-776. doi:10.4039/ENT121771-9

37. Sato, M. E., Veronez, B., Stocco, S. M. R., Queiroz, M. C. V. \& Ggallego, R., (2016), Spiromesifen resistance in Tetranychus urticae (Acari : Tetranychidae) : Selection, stability and monitoring. Crop Prot., 89 , 278 - 283. https:// doi.org/10.1016/j.cropro.2016.08.003

38. Shapiro, R. (2011). Prevention of vector transmitted disease with cove oil insect repellent. Journal of Pediatric Nursing, 27(4),346-349. doi: 10.1016/j.pedn.2011.03.011.

39. Sharawi, S. E., Abd-Alla, S. M., Omara, S. M., \& AlGhamdi, K. M. (2013). Surface contact toxicity of clove and rosemary oils against american cockroach, Periplaneta americana (L.). Afr. Entomol.21(2),324332. https://doi.org/10.4001/003.021.0204

40. Soliman, N. M. T. (2005). Evaluation the Pesticidal Action of Some Formulation of Plant Extracts; 111 PP. MS.C. Thesis, Institute of Environmental Studies and Research, Ain Shams University

41. Spanoghe, P. M. De Schampheleire, P. Van der Meeren \& W. Steurbaut. (2007). Influence of agricultural adjuvants on droplet Spectra. Pest management Science; 63(1), 416. doi: $10.1002 / p s .1321$

42. Van Leeuwen, T., Tirry, L. \& Nauen, R., (2006), Complete maternal inheritance of bifenazate resistance in Tetranychus urticae Koch (Acari : Tetranychidae) and its implications in mode of action considerations. Insect Biochem. Mol. Biol., 36 , 869 - 877. doi: 10.1016/j.ibmb.20 06.08.005.

43. Van, Leeuwen., Vontas, T. J. \& Sagkarakou, A. T. (2009). Mechanisms of acaricide resistance in the two-spotted spider mite Tetranychus urticae, 347-393. In I. Ishaaya and A. R. Horowitz (eds.), Biorational Control of Arthropod Pests. Springer, Dordrecht, the Netherlands.

44. Vassiliou, V. A. \& Kitsis, P., (2013), Acaricide resistance in tetranychus urticae (Acari: Tetranychidae) populations from Cyprus. J. Econ. Entomol., 106 (4) , 1848 - 1854. doi: http://dx.doi.org/10.1603/EC12369

45. World Health Organization (1979). Specification of Pesticides Used in Public Health, $5^{\text {th }}$ Ed. Geneva. 